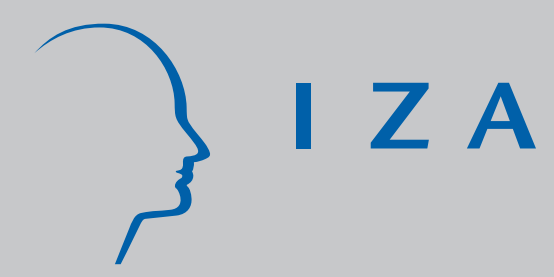

IZA DP No. 304

Labor Market Efficiency, Wages and Employment when Search Frictions Interact with Intrafirm Bargaining

Pierre Cahuc

Etienne Wasmer

J une 2001 


\title{
Labor Market Efficiency, Wages and Employment when Search Frictions Interact with Intrafirm Bargaining
}

\author{
Pierre Cahuc \\ Université Paris 1-Eurequa, Crest, Institut Universitaire de France and IZA, Bonn \\ Etienne Wasmer \\ ECARES, Université Libre de Bruxelles, CEPR and IZA, Bonn
}

Discussion Paper No. 304
June 2001

IZA

P.O. Box 7240

D-53072 Bonn

Germany

Tel.: +49-228-3894-0

Fax: +49-228-3894-210

Email: iza@iza.org

This Discussion Paper is issued within the framework of IZA's research area Internationalization of Labor Markets and European Integration. Any opinions expressed here are those of the author(s) and not those of the institute. Research disseminated by IZA may include views on policy, but the institute itself takes no institutional policy positions.

The Institute for the Study of Labor (IZA) in Bonn is a local and virtual international research center and a place of communication between science, politics and business. IZA is an independent, nonprofit limited liability company (Gesellschaft mit beschränkter Haftung) supported by the Deutsche Post AG. The center is associated with the University of Bonn and offers a stimulating research environment through its research networks, research support, and visitors and doctoral programs. IZA engages in (i) original and internationally competitive research in all fields of labor economics, (ii) development of policy concepts, and (iii) dissemination of research results and concepts to the interested public. The current research program deals with (1) mobility and flexibility of labor markets, (2) internationalization of labor markets and European integration, (3) the welfare state and labor markets, (4) labor markets in transition, (5) the future of work, (6) project evaluation and (7) general labor economics.

IZA Discussion Papers often represent preliminary work and are circulated to encourage discussion. Citation of such a paper should account for its provisional character. 
IZA Discussion Paper No. 304

June 2001

\title{
ABSTRACT \\ Labor Market Efficiency, Wages and Employment when Search Frictions Interact with Intrafirm Bargaining*
}

In search of a macroeconomic theory of wage determination, the agnostic reader should be puzzled by the apparent contradiction between two influential theories. On one hand, in the standard search-matching theory with wage bargaining, hiring cost and constant returns of labor, the bargaining power of employees allows them to get rents and gives rise either to overemployment or to under-employment compared with the first-best. On the other hand, in Stole and Zwiebel's theory of intrafirm bargaining with no hiring cost and decreasing returns of labor, the bargaining power of employees does not allow them to get rent and always gives rise to over-employment. In this paper, we try to reconcile the approaches. A simple matching model with large firms and diminishing marginal productivity of labor allows us to show that the two limit cases described above yield a mix of robust and non robust results: In the most general case, employees get rents and there is more frequently over-employment compared to the efficient allocation than in the standard search-matching model.

JEL Classification: J30, J50, J64

Keywords: Unemployment, wage bargaining, matching

\author{
Pierre Cahuc \\ Université Paris 1- EUREQua \\ Panthéon-Sorbonne \\ 106-112, Boulevard de l'Hôpital \\ 75013, Paris \\ France \\ E-mail : cahuc@univ-paris1.fr
}

"We thank Mathias Dewatripont, André Zylberberg and seminar participants at ECARES, ULB. 


\section{Introduction}

Real wages have consistently declined in the US between the early 70's and the mid 90's. Despite of a debate on the relevance of the price indices throughout this period, see e.g. Peter Gottschalk (1997), one may think that this evolution of wages is linked to the evolution of bargaining structures in line with the organization of firms. Indeed, the diffusion of new production methods, management practices and monitoring technologies, perhaps associated with the diffusion of technical progress and the IT revolution, is more and more likely to lead to an individualization of wage setting.

From this perspective, Lars Stole and Jeffrey Zwiebel's (1996a and b) papers are very provocative. Stole and Zwiebel provide a rigorous intrafirm bargaining model where employees and the firm engage in individual wage negotiation. Under the assumption that contract incompleteness does not enable either party to commit to future wages and employment decisions, they show that intrafirm, e.g. individual, bargaining yields no rent for employees and gives rise to over-employment compared to a competitive labor market. The basic idea of Stole and Zwiebel is that a firm, with a diminishing marginal productivity of labor, can decrease the bargained wage, which is proportional to the marginal productivity of labor, by increasing employment. In Stole and Zwiebel's setting, firms over-employ strategically, up to the point where workers get their reservation wage.

The underlying reason of workers' bargaining strength in their approach is, as clear from their bargaining structure, that employment during the bargaining stage is a fixed input, i.e. is predetermined, due to adjustment costs in employment left outside the model. Accordingly, and this is our starting point, an intrafirm bargaining analysis would be more relevant if conducted in a framework where such labor adjustment costs exist, and better, are endogenous to labor market conditions; what would happen then to the two proeminent results of Stole and Zwiebel, that wages are driven down to the reservation wage and to the over-employment result? And, to what extent the partial equilibrium approach they have taken affects some of the conclusions?

This is a difficult question to answer ex-ante; indeed, these results contrast quite drastically with those of the standard matching model of unemployment, which is likely one of the model the most often utilized to analyze unemployment. This model precisely incorporates a general equilibrium analysis of individual bargaining in the presence of adjustment costs to labor. It is thus a natural complementary theory of wages and employment.

In its standard form, developed by Christopher Pissarides (1985, 1990), and more recently by Dale Mortensen and Christopher Pissarides (1999), wages are bargained between each employer and employee, and each firm has only one job, that can be either vacant or filled. In this framework, it is well known that employees get a rent, since they benefit from a higher welfare than unemployed workers. Moreover, the condition under which wages are determined is not likely to lead to social efficiency, because there are trading externalities that are not taken into account during the negotiation process. More precisely, social efficiency is reached only if the so-called Hosios-Pissarides condition (see Arthur Hosios 1990) is fulfilled. This condition states that social efficiency is reached if the share of the surplus gotten by workers is equal to the elasticity of the matching function with respect to unemployment. Otherwise, there is under-employment if he workers' share is larger and over-employment if it is smaller.

It is widely accepted that the one firm-one job assumption is chosen for the sake of simplicity, and can easily generalize to a large firm, with many employees. Pissarides (1990, Chapter 2) provided an analysis of the negotiation process in the large firm. The results obtained by Pissarides are often evoked, but rarely proved in the particular framework in which they are used. For instance, David Andolfatto (1996), among many others, evoked Pissarides' results to utilize a matching model of 
the business cycle with large firms. ${ }^{1}$

Obviously, intrafirm bargaining cannot emerge if it is assumed that each firm has only one job, or if the marginal productivity of labor is constant, as it is done in the standard matching model of unemployment. In other words, to what extent Stole and Zwiebel analysis calls into question the results of the standard matching model of unemployment?

In order to answer this theoretical question we use a simple matching model with large firms that includes, as limit cases, the intrafirm bargaining model with no hiring cost and decreasing returns to labor on the one hand, and the standard matching model, with constant returns, small firms with one employee and hiring costs on the other hand.

This allows us to show that both limit cases yield a mix of robust and non robust results. In the general case, employees get rents and there is frequently over-employment, even when the Hosios-Pissarides condition is fulfilled.

The model is presented in Section 2. Section 3 is devoted to the analysis of the decentralized equilibrium with large firms. The decentralized equilibrium is compared to the efficient allocation in section 4. In the concluding comments of Section 5, we discuss the pros and the cons of each limit case.

\section{The model}

We consider a continuous time economy with two goods: A numeraire good, produced by firms, and labor, supplied by workers. There is a continuum of infinitely lived workers, which size is normalized to one. Each workers supplies one unit of labor. Search costs imply that firms need time and resources to hire workers. Accordingly, it is costly to replace an employee. The existence of worker replacement cost gives rise to negotiation within firms. Following Stole and Zwiebel, it is assumed that all wages are instantaneously and continuously negotiated. We shall first focus on the labor demand problem before presenting wage negotiation.

\subsection{Labor demand and hiring costs}

There is a large representative firm with diminishing marginal productivity of labor inputs ${ }^{2}$. Thus, production, denoted by $Y$, is obtained thanks to a concave production function denoted by $F(N)$, where $N$ stands for employment. To recruit, the firm incurs hiring costs per unit of time $\gamma$ and per vacancy posted. Assuming that the mass of aggregate contacts between the mass of vacancies, denoted by $V$, and unemployed $u$ is $h(u, V)$, a constant returns to scale function, increasing and concave in each argument, then, the probability to fill a vacant slot per unit of time is given by:

$$
h(u, V) / V=q(\theta) \text { with } q^{\prime}(\theta)<0, q(0)=+\infty,
$$

where $\theta=V / u$ denotes the ratio of vacancies to unemployed workers (the tightness of the labor market). Note that $\theta$ is exogenous to the firms' decisions.

The workers leave the firm with exogenous probability $s$. In our framework, employment $N$ is a state variable that cannot be increased instantaneously. Let us denote by $\Pi(N)$ the value of the

\footnotetext{
${ }^{1}$ Perhaps as a coïncidence (but is there any?), Andoffalto's article was released in the same issue of the A.E.R. as Stole and Zwiebel's paper. Importantly, it was recognized in the literature that decreasing returns to scale in a large firm search model would create complications and notably overemployment: The earliest paper ackowledging this result was Giuseppe Bertola and Ricardo Caballero (1994), more recents models with such feature being Ramon Marimon and Fabrizio Zilibotti (2000) and Giuseppe Bertola and Pietro Garibaldi (2001).

${ }^{2}$ Assuming decreasing returns to labor can amount to suppose constant returns to scale with predetermined capital stock. This assumption will be discussed below.
} 
firm, by $r$ its discount rate and by $w(N)$ the wage, possibly a function of the employment level of the firm, since wages are continuously and instantaneously negotiated at any employment level. Denoting employment at date $t$ by $N$, and employment at date $t+d t$ by $N^{+}$, the law of motion of jobs writes as:

$$
N^{+}=N(1-s d t)+V q(\theta) d t
$$

The value function of the firm, $\Pi(N)$, solves the Bellman equation:

$$
\Pi(N)=\operatorname{Max}_{\{V\}}\left(\frac{1}{1+r d t}\right)\left\{[F(N)-w(N) N-\gamma V] d t+\Pi\left(N^{+}\right)\right\},
$$

subject to the law of motion of jobs (1). The first-order and the envelope conditions for an optimal choice of $V$ write as:

$$
\begin{aligned}
-\gamma+q(\theta) J(N) & =0, \\
r J(N) & =F^{\prime}(N)-w^{\prime}(N) N-w(N)+\dot{J}(N)-s J(N),
\end{aligned}
$$

where $J(N)=\Pi^{\prime}(N)$, and the dot stands for the derivative with respect to time. Equation (4) shows that the marginal value of a job depends on the impact of a marginal hiring on the wage of all workers, i.e. $-N w^{\prime}(N)$.

\subsection{Intra-firm wage bargaining}

The expected discounted value of employment is denoted by $E$, whereas the expected discounted value of unemployment is denoted by $U$. If $b$ denotes the utility flow of risk-neutral workers when non-employed, then $E$ and $U$ solve:

$$
\begin{aligned}
& r E=w(N)+s(U-E)+\dot{E}, \\
& r U=b+p(\theta)(E-U)+\dot{U},
\end{aligned}
$$

where $p(\theta)=h(u, V) / u=\theta q(\theta)$ with $p^{\prime}(\theta)>0$, stands for the instantaneous matching probability of unemployed workers

Wages are continuously and instantaneously negotiated. Since firms need time to hire workers, employment is considered as a state variable during the negotiation process. Wages are determined according to the usual Nash bargaining game given the mass of employees present in the firm: This implies that the surplus of each job is shared according to the rule:

$$
\beta J(N)=(1-\beta)(E-U),
$$

where $\beta \in[0,1]$ is an index of the bargaining power of workers. It is worth noticing that labor demand (3) implies that the marginal value of a job is always non negative. Accordingly, the surplus sharing rule (7) implies that $E \geq U$.

Given the value $J(N)$ of a marginal job, defined in equation (4), the surplus sharing rule (7) together with (5) and (6) defines a differential equation for $w(N)$, which writes, in a steady state, as:

$$
w(N)=(1-\beta) r U+\beta\left[F^{\prime}(N)-N w^{\prime}(N)\right] .
$$

This form of wage equation, derived by Stole and Zwiebel, is different from the equation usually obtained in the standard matching model with constant returns to scale, in which the term $N w^{\prime}(N)$ 
does not appear. Here, this term is present, because one takes into account that firms renegotiate all wages if an employee quits after a disagreement. Stole and Zwiebel argue convincingly that wage equation (8) defines a "stable" wage profile in which, prior to production, no individual employee can benefit from a renegotiation with the firm, and the firm cannot benefit from renegotiation with any employee given the further wage renegotiations that such a renegotiation would induce.

Equation (8) solves ${ }^{3}$ as:

$$
w(N)=(1-\beta) r U+N^{-1 / \beta} \int_{0}^{N} x^{\frac{1-\beta}{\beta}} F^{\prime}(x) d x .
$$

Henceforth, for the sake of simplicity, it is worth using a Cobb-Douglas formulation for $F(N)=$ $N^{\alpha}$, then, one gets:

$$
w(N)=r U+\beta\left[\frac{F^{\prime}(N)}{1-\beta(1-\alpha)}-r U\right]
$$

The wage is equal to the reservation wage, $r U$, plus a term that will be shown to be positive in equilibrium.

\section{Labor market equilibrium}

\subsection{Existence and Uniqueness}

One can now determine, first the wage profile, second the (unique) level of equilibrium employment and labor market tighness.

Indeed, in equilibrium, (3), (4), (5), (6) and (7) imply that the wage satisfies:

$$
w(N)=r U+\frac{\gamma}{q(\theta)} \frac{\beta}{1-\beta}(r+s)
$$

It is interesting to remark that, despite intrafirm bargaining, the wage paid to workers when firms have made their optimal employment decisions is above the reservation wage, $r U$, contrary to Stole and Zwiebel, but that the wage (as shown below) goes continuously to the reservation wage when search frictions (represented by search costs $\gamma$ ) vanish.

We can now establish the existence and uniqueness of the equilibrium value of $(N, \theta)$ or more conveniently, of $(u, \theta)$ where $u=1-N$ is the unemployment rate. The steady state equilibrium value of $\theta$ and $u$ can be defined by two equations. First, there is a steady-state condition on flows of workers between employment and unemployment. There are $u \theta q(\theta)$ exits from unemployment and $(1-u) s$ entry into unemployment per unit of time. Accordingly, the flow equilibrium reads:

$$
(1-u) s=u \theta q(\theta)
$$

This labor flow equilibrium (12), referred to as the Beveridge Curve, defines a negative relation in the plane $(\theta, u)$ with limits $(+\infty, 0)$ and $(0,1)$ - see Figure 1.

\footnotetext{
${ }^{3}$ One assumes as in Stole and Zwiebel that the conditions for the existence of the integral in (10) are satisfied (these conditions are not very restrictive). This allows us to get rid of the constant term in the solution for the wage: In this case, this constant term can be shown to be zero, under the supplementary condition that the wage is finite when $N \rightarrow 0$.
} 


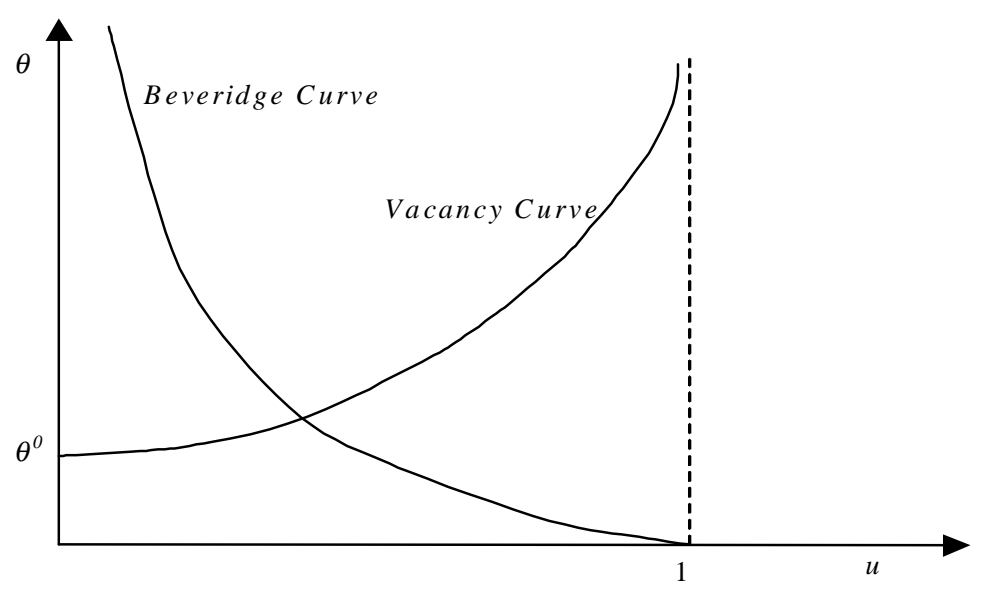

Figure 1: The labor market equilibrium.

Second, combining the labor demand defined by (3) and (4), and the wage equation (10), together with the identity $N=1-u$, and after manipulations ${ }^{4}$, one gets:

$$
F^{\prime}(1-u)=[1-\beta(1-\alpha)]\left\{b+\frac{\gamma}{1-\beta}\left[\beta \theta+\frac{r+s}{q(\theta)}\right]\right\} .
$$

This equation defines a Vacancy Curve, which is a positive relation between the unemployment rate and the labor market tightness in the plane $(\theta, u)$, with limits $\left(\theta^{0}, 0\right)$ and $(+\infty, 1)$, where $\theta^{0}$ is defined by $F^{\prime}(1)=[1-\beta(1-\alpha)]\left\{b+\frac{\gamma}{1-\beta}\left[\beta \theta^{0}+\frac{r+s}{q\left(\theta^{0}\right)}\right]\right\}$. Accordingly, (12) and (13) define a unique equilibrium with $\theta>0, u \in] 0,1[$.

\subsection{Limit cases}

Let us first focus on a limit case in which the production function exhibits constant returns to scale (in Cahuc and Wasmer 2001, we showed that this corresponds to the case with perfect capital adjustment and constant returns to scale in total factors, as discussed in Pissarides, 1990). In that case, one has $\alpha=1$, and $F^{\prime}(N)$ is a constant, denoted by $y$, assuming $y>b$ in order to get a non-trivial solution with positive employment. The results obtained here are exactly those of the standard matching model. Indeed, from $(10), w=(1-\beta) r U+\beta y$ implying that $F^{\prime}(N)>w>r U$ : Employees get rents and the marginal productivity of labor is larger than the wage.

The basic model of Stole and Zwiebel, with decreasing returns to scale and no hiring cost, delivers very different results. This can be shown by studying the limit case in which $\gamma \rightarrow 0$. In that case, assuming that $F^{\prime}(1)>b,(12)$ and (13) imply - see appendix A - an infinite labor market tightness with full employment $(u=0)$. Thus, (11) and (13) imply:

$$
w=r U=F^{\prime}(1) /(1-\beta(1-\alpha))>F^{\prime}(1) .
$$

From equation (14), one can deduce that intrafirm bargaining with decreasing returns to scale and no hiring cost yields no rent for employees and a marginal productivity of labor smaller than the wage.

\footnotetext{
${ }^{4}$ Notably, $r U$ on the right hand side of (10) is obtained from $(3),(4),(6)$ and (7) and writes $r U=b+[\gamma \beta \theta /(1-\beta)]$.
} 
The intuition is a straight application of Stole and Zwiebel's results. The wage equation (10) shows that wages decrease when employment increases, given that the marginal product and hence the surplus will decrease with employment. Firms thus can strategically exploit this feature to increase employment and to reduce their wage bill. What happens here is that firms over-employ compared to the competitive case in which the effect of employment on the wage is not taken into account. As shown by equation (14), in equilibrium, this over-employment behavior entails a marginal productivity of labor smaller than the reservation wage. This leads to a higher labor market tightness than in a situation in which the marginal productivity of labor is equal to the reservation wage.

These results are exactly opposed to those obtained with constant returns to scale and hiring costs. What is going on in the general case, with decreasing returns and positive (and finite) hiring costs?

\subsection{General case}

Figures 2 and 3 show that the ranking of the marginal productivity of labor, the wage and the reservation wage, met in both limit cases are satisfied for particular ranges of the hiring cost $\gamma$ and the returns to scale parameter $\alpha$.

On Figure 2, it can be seen that Stole and Zwiebel's case, in which $F^{\prime}(N)<w=r U$, can arise only for $\gamma=0$. In this particular case, workers have no rent. Figure 2 clearly shows that, on this issue, Stole and Zwiebel conclusion is not robust. Actually, in their paper, employees never get rent because there is either no hiring costs, or hiring costs that can be shared between employers and employees thanks to commitment made before recruitment. If some hiring costs are not contractible, which seems compatible with Stole and Zwiebel's assumption of contract incompleteness, workers get rents. However, one can see, on Figure 2, that the marginal productivity of labor is smaller than the wage for positive values of $\gamma$. On this issue, Stole and Zwiebel's analysis yields more robust results.

The situation described by the standard matching model, in which $F^{\prime}(N)>w>r U$, is met only if the hiring cost is sufficiently high. For intermediate values of the hiring cost, the labor marginal productivity can be smaller than both the wage and the reservation wage, or in between the reservation wage and the wage.

Figure 3 shows that the situation met in the standard matching model arises only if the technology is close to constant returns to scale. In our example, it appears that the labor marginal productivity is bigger than the wage for a small range of values of $\alpha$. In particular, if one interprets the technology as a standard Cobb-Douglas production function with a predetermined capital stock, $\alpha$ amounts to about $2 / 3$, and Figure 3 shows that the marginal productivity of labor is smaller than both the wage and the reservation wage.

At this stage, we know that workers obtain some rent at least when firms incur some hiring costs. In that sense, one may be led to think that Stole and Zwiebel's prediction that there is over-employment is a very specific case. However, such is not the result one gets when deriving the welfare analysis that follows.

\section{Efficiency}

In the standard matching model with constant returns to scale, the decentralized equilibrium with wage bargaining is efficient if and only if $\beta=\eta(\theta)$, with $\left.\eta(\theta)=-\theta q^{\prime}(\theta) / q(\theta) \in\right] 0,1[$. This is the Hosios-Pissarides condition. Let us define the steady state efficient solution when there are 


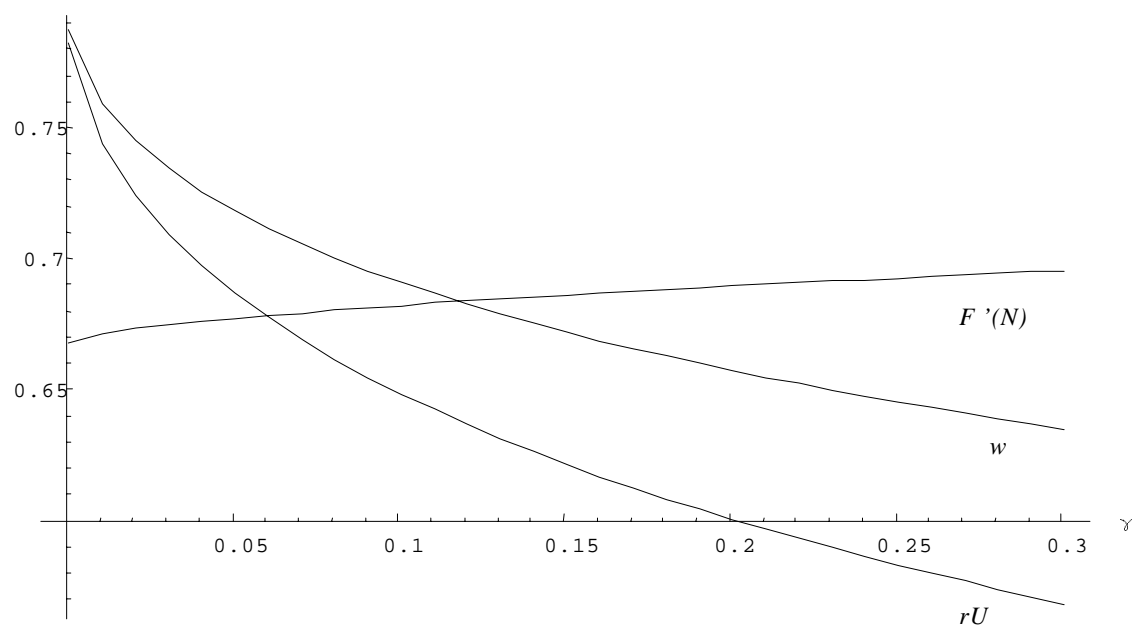

Figure 2: The consequence of hiring costs on the marginal productivity of labor, the reservation wage and the wage. Parameters values are: $\alpha=2 / 3, b=0.2, h(u, V)=\sqrt{u \cdot V}, s=0.15, r=0.05$

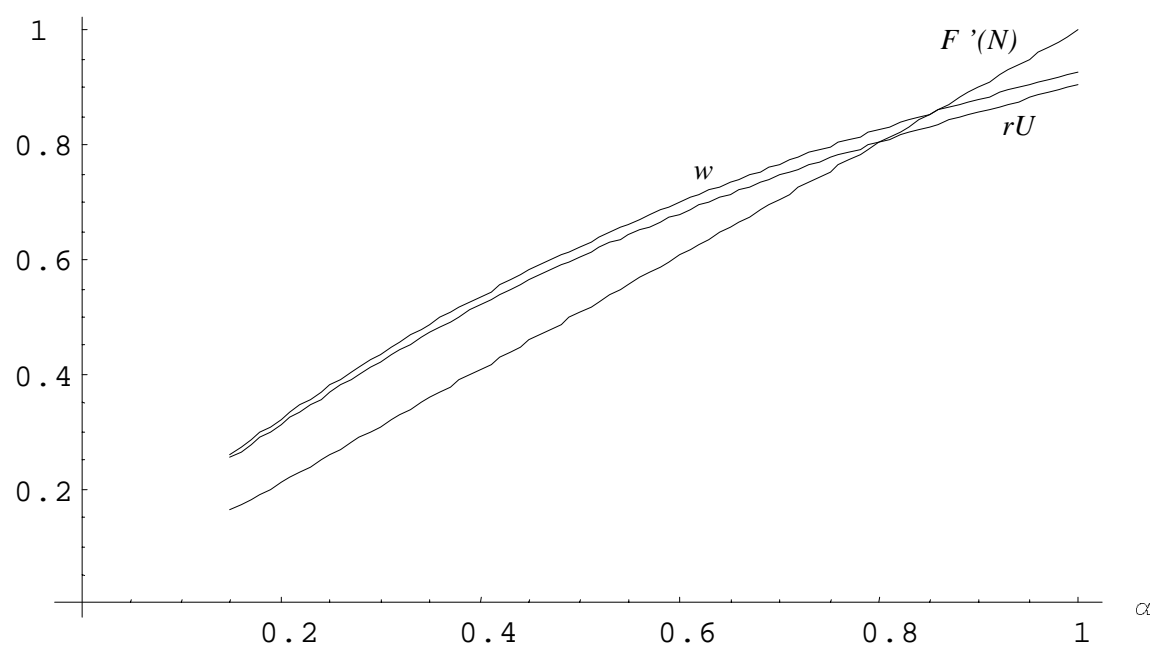

Figure 3: The consequence of returns to scale on the marginal productivity of labor, the reservation wage and the wage. Parameters value are: $\gamma=0.02, b=0.2, h(u, V)=\sqrt{u \cdot V}, s=0.15, r=0.05$ 
decreasing returns to scale. Ignoring discounting for the sake of simplicity, the social planner problem reads as:

$$
\operatorname{Max}_{\theta} F(1-u)+b u-\gamma \theta u \text { subject to } u=\frac{s}{s+\theta q(\theta)}
$$

The first-order condition yields:

$$
(1-\eta)\left[F^{\prime}(1-u)-b\right]=\frac{\gamma}{q(\theta)}[s+\eta(\theta) \theta q(\theta)]
$$

Equations (3), (4), (6) and (8) allow us to write the decentralized equilibrium as:

$$
(1-\beta)\left[F^{\prime}(1-u)-b-(1-u) w^{\prime}(1-u)\right]=\frac{\gamma}{q(\theta)}[s+\beta \theta q(\theta)]
$$

It is worth noting that condition (16) defines, together with the flow equilibrium condition (12), a relation between $\theta$ and $\beta$ that is not necessarily monotonic - see Appendix B, equation (20). The implication of this result is that, in the decentralized equilibrium, the labor market tightness $\theta$, and thus employment, may have non monotonic variations with respect to the index of bargaining power of worker $\beta$. There are two contributions of $\beta$ to the variations of $\theta$ :

- a negative one, due to the effect usually met in matching models: Less surplus accruing to the firm reduces job creations and thus $\theta$.

- a positive one, due to the fact that firms exploit the possibility of intra-firm bargaining, and over-employ to reduce worker's wages. A higher bargaining power of workers makes this possibility even more attractive for firms, exactly in the spirit of Stole and Zwiebel ${ }^{5}$.

The effect of $\beta$ on wages and then on employment decisions is thus ambiguous. Such a case of non-monotonocity is illustrated on Figure 4, plotting $u(\beta)$ by exploiting the one-to-one correspondence between $\theta$ and $u$. This example is obtained with values of the parameters that differ from the previous case. Notably, $\alpha$ has been set to a lower value, namely $1 / 4$.

Substracting the equations (16) and (15), one gets a condition that insures that the decentralized equilibrium is efficient:

$$
\beta=\eta(\theta)+\Lambda, \quad \text { with } \Lambda=-\frac{(1-u) w^{\prime}(1-u)(1-\beta)}{F^{\prime}(1-u)-b+\gamma \theta} \geq 0
$$

This is a modified Hosios-Pissarides condition (i.e. $\beta=\eta$ ) which obviously corresponds to the Hosios-Pissarides condition when wages do not react to changes in employment, i.e. $w^{\prime}=0$.

As illustrated in Figure 4, where the socially optimal value of $\theta$ (equivalently, $u$ ) is also reported (note that it is independent of $\beta$ ), the decentralized equilibrium and the social optimum coincide sometimes, here for a value of $\beta \simeq 0.98$ much higher than the conventional $\eta=0.5$ of the HosiosPissarides condition. What happens here is that, due to the presence of the term $\Lambda>0$, itself resulting from $w^{\prime}(\theta)<0$, firms need a higher $\beta$ than in the standard Pissarides case to obtain the same tightness of the labor market, since again they can exploit the diminishing returns to scale to reduce the wage.

\footnotetext{
${ }^{5}$ This actually can be easily be seen from the expression (10) of the wage, which implies that $w^{\prime}(N)=$ $\beta F^{\prime \prime}(N) /[1-\beta(1-\alpha)]$, which absolute value increases with $\beta$ at constant $N$.
} 


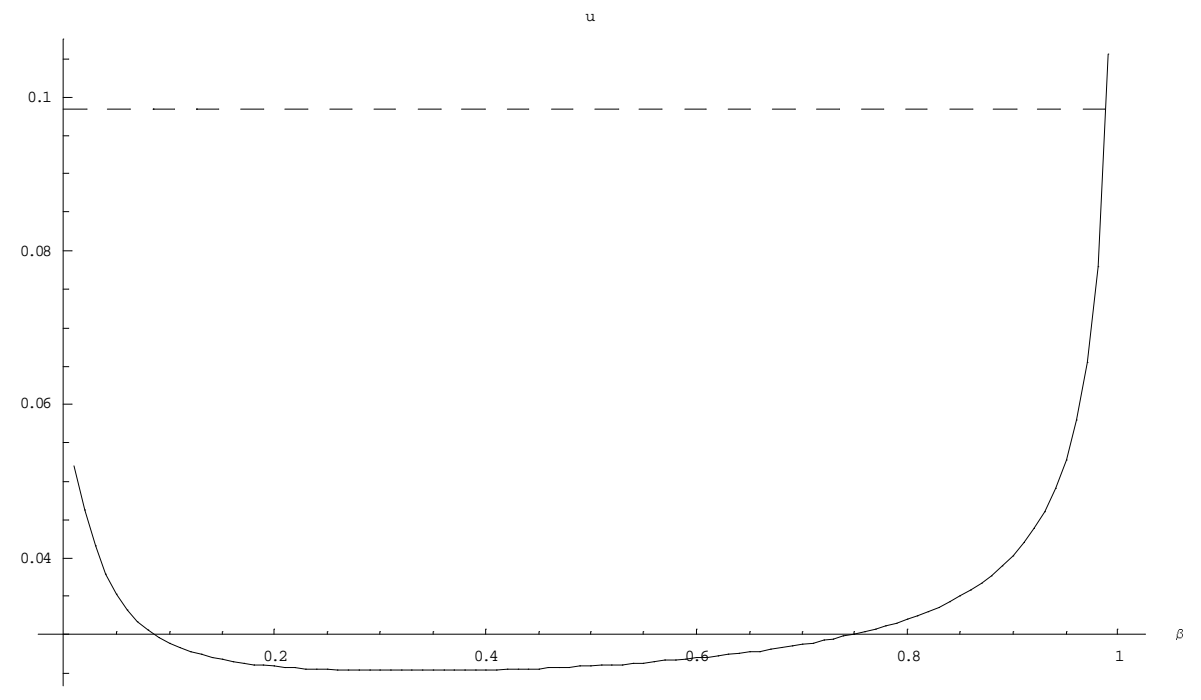

Figure 4: The efficient (dotted line) and the decentralized (continuous line) unemployment rate. Parameters value are: $\gamma=0.02, b=0.26, h(u, V)=\sqrt{u \cdot V}$, $s=0.2, r=0.05, \alpha=0.25$.

This effect is large in this example, and may lead to think that, sometimes, it is even impossible to reach an efficient allocation when there is both intra-firm wage bargaining and strong decreasing returns to scale: If indeed $\Lambda$ was large enough, no $\beta$ may insure the equality in (17). One may remember a similar result by Giuseppe Bertola and Ricardo Caballero (1994), also obtained in a matching model with intra-firm bargaining and heterogeneous search costs ${ }^{6}$. However, this is not the case in our framework: We can prove that $\Lambda$ is never large enough to eliminate the possibility of an efficient decentralized equilibrium - see Appendix B. As illustrated in Figure 4, when $\beta$ is large enough, there is under-employment, and when $\beta$ is low enough, there is over-employment.

There are two additional remarks here: First, the non-monotonicity may suggest that several values of $\beta$ insure a socially optimum private equilibrium. However, we have not observed this in our simulations - because there is always over-employment as $\beta \rightarrow 0$. Second, the high value of $\beta \simeq 0.98$ insuring the efficiency would suggest that the over-employment result of Stole and Zwiebel is much more likely than in the standard matching analysis: In other words, far fewer values of the bargaining power $\beta$ lead to under-employment than it can be deduced from the standard matching model.

\section{Concluding comments}

We have shown that employees are likely to get rents even though firms play strategically with decreasing returns through intrafirm wage bargaining. In that sense, conclusions of the standard matching model are quite robust, since search frictions and individual bargaining provide employees with quasi-rents. However, as soon as intra-firm bargaining is introduced in the general model, a

\footnotetext{
${ }^{6}$ More precisely, Bertola and Caballero argue that the discrepancy between private and socially optimal allocations relies on heterogeneity, claiming that "a social planner would need to use as many instruments as there are active margins, and altering the Nash bargaining parameter $\beta$ is not enough in the presence of cross-sectional dynamic heterogeneity" (p. 454).
} 
conclusion that was reached in Stole and Zwiebel (1996) is somehow justified, though tempered: Namely, firms tend to over-employ - compared to the social optimum - more frequently than what can be deduced from the standard matching analysis.

Both Pissarides (1990) and Stole and Zwiebel's results rely on fast adjustment processes. Indeed, in Pissarides, the constant returns to scale assumption is realistic only in the case of instantaneous adjustment of the stock of capital, as Pissarides discusses and as we emphasized in Cahuc and Wasmer (2001). Stole and Zwiebel's main results hold, only when firms and workers intantaneously renegotiate wages at each change in the level of employment, notably when an individual employee leaves because he disagrees with the employer in the wage bargaining process. Since it is conventionally believed that firms actually face severe adjustment costs adopting new capital, selling old capital or when bargaining wages, a general model of intrafirm bargaining in presence of such adjustments costs is necessary to have a better understanding of the effect of distortions due to search frictions and wage bargaining on employment, real wages and economic efficiency. Our paper, beyond the necessary clarification of these issues, is a first step in this direction.

\section{References}

[1] Andolfatto, David. "Business Cycle and Labor-Market Search", American Economic Review, March 1996, 86(1), pp. 112-132.

[2] Bertola, Giuseppe and Pietro Garibaldi. "Wage Structure and the Size of Firms in Dynamic Matching Models", mimeo, Universita' Bocconi, forthcoming, Review of Economic Dynamics, 2001.

[3] Caballero, Ricardo and Mohammad Hammour. "On the Timing and Efficiency of Creative Destruction", Quarterly Journal of Economics, 1996, 111, pp. 805-52.

[4] Cahuc, Pierre and Etienne, Wasmer. "Does Intrafirm Bargaining Matter in the Large Firm's Matching Model?" forthcoming in Macroeconomic Dynamics, 2001.

[5] Gottschalk, Peter. (1997). "Inequality, Income Growth, and Mobility: The Basic Facts", Journal of Economic Perpsectives, Spring 1997, 11, pp21-40

[6] Hosios, Arthur J. "On the Efficiency of Matching and Related Models of Search and Unemployment", Review of Economic Studies, April 1990, 57(2), pp. 279-98.

[7] Marimon, Ramon and Fabrizio Zilibotti (2000). "Employment and Distributional Effects of Restricting Working Time“", European Economic Review, 44(7), June 2000, pages 1291-1326.

[8] Mortensen, Dale T. and Christopher, A. Pissarides. "New developments in Models of Search in the Labor Market", Mimeo, Northwestern University, 1999.

[9] Pissarides, Christopher, A. "Short-Run Equilibrium Dynamics of Unemployment Vacancies, and Real Wages.".American Economic Review, September 1985, 75(?), pp.676-90.

[10] Pissarides, Christopher, A. Equilibrium Unemployment Theory, Oxford, Basil Blackwell, 1990.

[11] Stole, Lars A. and Jeffrey Zwiebel. "Intrafirm Bargaining under Non-binding Contracts". Review of Economic Studies, March 1996, vol 63, pp. 375-410. 
[12] Stole, Lars A. and Jeffrey Zwiebel. "Organizational Design and Technology Choice under Intrafirm Bargaining". American Economic Review, March 1996, 86(1), pp. 195-222. 


\section{Appendix}

\section{A The case with zero hiring cost}

Let us study the equilibrium when $\gamma \rightarrow 0$. Equation (13) can be written as:

$$
\beta \theta+\frac{r+s}{q(\theta)}=\frac{1-\beta}{\gamma}\left[\frac{F^{\prime}(1-u)}{1-\beta(1-\alpha)}-b\right]
$$

Since we assume that $F^{\prime}(1)>b$, one gets $\left[\frac{F^{\prime}(1-u)}{1-\beta(1-\alpha)}-b\right]>0$ for $u \in[0,1]$, and (18) implies that $\left[\beta \theta+\frac{r+s}{q(\theta)}\right]$ goes to infinity. Under the conventional assumption that $q(\theta)$ goes to 0 when $\theta$ goes to infinity (simply equivalent to having a zero recruitment rate for firms when the ratio of vacancy to workers goes to zero), this implies necessarily that $\theta$ has to go to infinity when $\gamma \rightarrow 0$. Therefore, (12) implies that $u=0$. Thus, equation (13) implies that the term $\frac{\gamma}{1-\beta}\left[\beta \theta+\frac{r+s}{q(\theta)}\right]$ converges to a finite number denoted by $K$ where

$$
K+b=F^{\prime}(1) /(1-\beta(1-\alpha))
$$

In addition, under the assumption of strictly decreasing returns to scale for each argument in matching, the term $\beta \theta$ dominates the ter $\frac{r+s}{q(\theta)}$ when $\theta$ tends to infinity (to see this, notice that the term $\frac{1}{q(\theta)} \sim_{+\infty} \theta^{\eta(\theta)}$ where $0<\eta(\theta)<1$ is the elasticity of $q$ to $\theta)$. This means that $\gamma \theta \frac{\beta}{1-\beta} \rightarrow K$. This implies that the reservation wage $r U=b+\gamma \theta \frac{\beta}{1-\beta}$ tends to $b+K=F^{\prime}(1) /(1-\beta(1-\alpha))$. Thus, equation (10) entails equation (14).

\section{B Welfare}

Using the labor flow equilibrium equation (12), condition (15) can be written as:

$$
F^{\prime}\left(\frac{\theta q(\theta)}{s+\theta q(\theta)}\right)=b+\frac{\gamma}{q(\theta)[1-\eta(\theta)]}[s+\eta(\theta) \theta q(\theta)] \equiv P(\theta)
$$

Using (10) and (12), condition (16) also reads:

$$
F^{\prime}\left(\frac{\theta q(\theta)}{s+\theta q(\theta)}\right)=[1-\beta(1-\alpha)]\left\{b+\frac{\gamma}{q(\theta)(1-\beta)}[s+\beta \theta q(\theta)]\right\} \equiv D(\theta, \beta)
$$

It can be easily checked that $d F^{\prime}\left(\frac{\theta q(\theta)}{s+\theta q(\theta)}\right) / d \theta<0$, and $\partial D(\theta, \beta) / \partial \theta>0$. One can also check that $P(\theta)>D(\theta, \eta(\theta))$, which implies that labor market tightness in the decentralized equilibrium, denoted by $\theta_{d}$, is bigger than its efficient value, denoted by $\theta_{p}$ if the Hosios-Pissarides condition is fulfilled. This property, together with the labor flow equilibrium equation (12), which indicates that the unemployment rate decreases with the labor market tightness, allows us to conclude that there is over-employment if the Hosios-Pissarides condition if fulfilled.

Moreover, $\operatorname{Lim}_{\beta \rightarrow \mathbf{0}} D(\theta, \beta)=b+\frac{\gamma s}{q(\theta)}<P(\theta), \forall \theta>0$. As shown on Figure 5 , this implies that $\theta_{d}>\theta_{p}$. Therefore, there exist values of $\beta$, sufficiently close to zero, which imply over-employment in the decentralized equilibrium. 


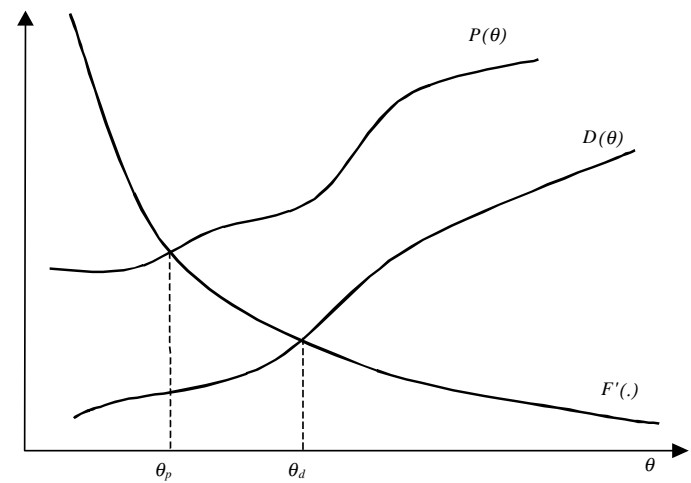

Figure 5: The value of $\theta$ when $\beta \rightarrow 0$.

One also gets $\operatorname{Lim}_{\beta \rightarrow 1} D(\theta, \beta)=+\infty>P(\theta), \forall \theta>0$. Looking at Figure 5 , it can be seen that this implies that $\theta_{d}<\theta_{p}$ if $\beta \rightarrow 1$. Thus, there exist values of $\beta$, sufficiently close to one, which imply under-employment in the decentralized equilibrium in a neighborhood of $\beta=1$. Note that this is a proof of existence, not of unicity, as the non-monotonicity in Figure 4 suggests. 


\section{IZA Discussion Papers}

\begin{tabular}{|c|c|c|c|c|}
\hline No & Author(s) & Titel & Area & Date \\
\hline 221 & C. Grund & Wages as Risk Compensation in Germany & 5 & $12 / 00$ \\
\hline 222 & W.P.M. Vijverberg & Betit: A Family That Nests Probit and Logit & 7 & $12 / 00$ \\
\hline 223 & $\begin{array}{l}\text { M. Rosholm } \\
\text { M. Svarer }\end{array}$ & $\begin{array}{l}\text { Wages, Training, and Job Turnover in a Search- } \\
\text { Matching Model }\end{array}$ & 1 & $12 / 00$ \\
\hline 224 & J. Schwarze & $\begin{array}{l}\text { Using Panel Data on Income Satisfaction to } \\
\text { Estimate the Equivalence Scale Elasticity }\end{array}$ & 3 & $12 / 00$ \\
\hline 225 & $\begin{array}{l}\text { L. Modesto } \\
\text { J. P. Thomas }\end{array}$ & $\begin{array}{l}\text { An Analysis of Labour Adjustment Costs in } \\
\text { Unionized Economies }\end{array}$ & 1 & $12 / 00$ \\
\hline 226 & P. A. Puhani & $\begin{array}{l}\text { On the Identification of Relative Wage Rigidity } \\
\text { Dynamics: A Proposal for a Methodology on } \\
\text { Cross-Section Data and Empirical Evidence for } \\
\text { Poland in Transition }\end{array}$ & $4 / 5$ & $12 / 00$ \\
\hline 227 & L. Locher & $\begin{array}{l}\text { Immigration from the Eastern Block and the } \\
\text { former Soviet Union to Israel: Who is coming } \\
\text { when? }\end{array}$ & 1 & $12 / 00$ \\
\hline 228 & $\begin{array}{l}\text { G. Brunello } \\
\text { S. Comi } \\
\text { C. Lucifora }\end{array}$ & $\begin{array}{l}\text { The College Wage Gap in } 10 \text { European } \\
\text { Countries: Evidence from Two Cohorts }\end{array}$ & 5 & $12 / 00$ \\
\hline 229 & $\begin{array}{l}\text { R. Coimbra } \\
\text { T. Lloyd-Braga } \\
\text { L. Modesto }\end{array}$ & $\begin{array}{l}\text { Unions, Increasing Returns and Endogenous } \\
\text { Fluctuations }\end{array}$ & 1 & $12 / 00$ \\
\hline 230 & L. Modesto & $\begin{array}{l}\text { Should I Stay or Should I Go? Educational } \\
\text { Choices and Earnings: An Empirical Study for } \\
\text { Portugal }\end{array}$ & 5 & $12 / 00$ \\
\hline 231 & G. Saint-Paul & The Economics of Human Cloning & 5 & $12 / 00$ \\
\hline 232 & $\begin{array}{l}\text { E. Bardasi } \\
\text { M. Francesconi }\end{array}$ & $\begin{array}{l}\text { The Effect of Non-Standard Employment on } \\
\text { Mental Health in Britain }\end{array}$ & 5 & $12 / 00$ \\
\hline 233 & $\begin{array}{l}\text { C. Dustmann } \\
\text { C. M. Schmidt }\end{array}$ & $\begin{array}{l}\text { The Wage Performance of Immigrant Women: } \\
\text { Full-Time Jobs, Part-Time Jobs, and the Role of } \\
\text { Selection }\end{array}$ & 1 & $12 / 00$ \\
\hline 234 & $\begin{array}{l}\text { R. Rotte } \\
\text { M. Steininger }\end{array}$ & $\begin{array}{l}\text { Sozioökonomische Determinanten extremistischer } \\
\text { Wahlerfolge in Deutschland: Das Beispiel der Eu- } \\
\text { ropawahlen } 1994 \text { und } 1999\end{array}$ & 3 & $12 / 00$ \\
\hline
\end{tabular}


236 R. Hujer

M. Caliendo

237 S. Klasen

I. Woolard

238 R. Euwals

A. Börsch-Supan

A. Eymann

239 F. Andersson

K. A. Konrad

240 W. Koeniger

241 W. Koeniger

242 G. Faggio

J. Konings

243

E. Brainerd

244 S. M. Fuess, Jr. M. Millea

245 F. Andersson

K. A. Konrad

246 E. Plug

W. Vijverberg

247 E. Plug

W. Vijverberg

248 P. M. Picard

E. Toulemonde

249

B. M. S. van Praag

P. Cardoso

250

T. J. Hatton

J. G. Williamson
Evaluation of Active Labour Market Policy:

6

$12 / 00$

Methodological Concepts and Empirical

Estimates

Surviving Unemployment without State Support: 3

$12 / 00$

Unemployment and Household Formation in

South Africa

The Saving Behaviour of Two Person House-

5

$12 / 00$

holds: Evidence from Dutch Panel Data

Human Capital Investment and Globalization in

Extortionary States

5

01/01

Labor and Financial Market Interactions: The

5

$01 / 01$

Case of Labor Income Risk and Car Insurance in the UK 1969-95

Trade, Labor Market Rigidities, and Government- 2 Financed Technological Change

$01 / 01$

Job Creation, Job Destruction and Employment 4

Growth in Transition Countries in the 90's

$01 / 01$

Economic Reform and Mortality in the Former

4

$01 / 01$

Soviet Union: A Study of the Suicide Epidemic in the 1990s

Pay and Productivity in a Corporatist Economy: 5

$01 / 01$

Evidence from Austria

Globalization and Human Capital Formation

5

$01 / 01$

Schooling, Family Background, and Adoption:

5

$01 / 01$

Does Family Income Matter?

Schooling, Family Background, and Adoption:

5

$01 / 01$

Is it Nature or is it Nurture?

The Impact of Labor Markets on Emergence and 2

Persistence of Regional Asymmetries

01/01

"Should I Pay for You or for Myself?"

3

01/01

The Optimal Level and Composition of

Retirement Benefit Systems

Demographic and Economic Pressure on

Emigration out of Africa 
254 H. Gersbach

A. Schniewind

255 H. Gersbach

A. Schniewind

T. Boeri

H. Brücker

257

T. Boeri

258

M. Rosholm

K. Scott

L. Husted

259

A. Ferrer-i-Carbonell

B. M.S. van Praag

260

P. Cahuc

F. Postel-Vinay

261

M. Lindahl

262

M. Lindahl

263

N. Datta Gupta

N. Smith

264

C. Dustmann

265

M. Rosholm

M. Svarer

C. Dustmann

O. Kirchkamp
Learning of General Equilibrium Effects and the Unemployment Trap

3

02/01

Product Market Reforms and Unemployment in 3 Europe

Eastern Enlargement and EU-Labour Markets: 2 Perceptions, Challenges and Opportunities

Transition with Labour Supply

4

02/01

The Times They Are A-Changin':

1

$02 / 01$

Organizational Change and Immigrant

Employment Opportunities in Scandinavia

Poverty in the Russian Federation

4

$02 / 01$

Temporary Jobs, Employment Protection and

$1 / 3$

02/01

Labor Market Performance

Home versus School Learning:

5

02/01

A New Approach to Estimating the Effect of Class Size on Achievement

Summer Learning and the Effect of Schooling:

5

02/01 Evidence from Sweden

Children and Career Interruptions:

5

02/01

The Family Gap in Denmark

Return Migration, Wage Differentials, and the

1

02/01 Optimal Migration Duration

Structurally Dependent Competing Risks

02/01

The Optimal Migration Duration and Activity Choice after Re-migration 
283 M. Hagedorn

A. Kaul

V. Reinthaler

284

H. Rapoport

A. Weiss

285

J. Jerger

C. Pohnke

A. Spermann

286 M. Fertig

C. M. Schmidt

287 P. Guggenberger

A. Kaul

M. Kolmar

288

D. A. Cobb-Clark

289

L. Cameron

D. A. Cobb-Clark

290

D. A. Cobb-Clark

M. D. Connolly

C. Worswick

291

R. T. Riphahn

292

E. Wasmer

293

D. Cobb-Clark

T. F. Crossley

294 Š. Jurajda

295
F. Duffy
P. P. Walsh

296 H. S. Nielsen

M. Rosholm

N. Smith

L. Husted
Welfare Analysis in a Schumpeterian Growth

Gut betreut in den Arbeitsmarkt?

5

04/01

Eine mikroökonometrische Evaluation der

Mannheimer Arbeitsvermittlungsagentur

First- and Second-Generation Migrants in

People Think

Efficiency Properties of Labor Taxation in a

3

04/01

Spatial Model of Restricted Labor Mobility

Getting Ahead: The Determinants of and Payoffs

5

$04 / 01$ to Internal Promotion for Young U.S. Men and Women

Old-Age Support in Developing Countries:

Labor Supply, Intergenerational Transfers and

Living Arrangements

The Job Search and Education Investments of

04/01 Immigrant Families

$05 / 01$

Cohort Effects in the Educational Attainment of Second Generation Immigrants in Germany: An Analysis of Census Data

Between-group Competition in the Labor Market and the Rising Returns to Skill: US and France 1964-2000

Gender, Comparative Advantage and Labor

05/01 Market Activity in Immigrant Families

Estimating the Effect of Unemployment

$05 / 01$ Insurance Compensation on the Labor Market Histories of Displaced Workers

Individual Pay and Outside Options:

05/01

Evidence from the Polish Labour Force Survey

4 
297 J. C. van Ours J. Veenman

298 P. Telhado Pereira P. Silva Martins

G. Brunello

C. Lucifora

R. Winter-Ebmer

300 A. Stutzer

R. Lalive

301 J. R. Frick

G. G. Wagner

302

G. S. Epstein

A. Weiss

303

B. F. Blumberg

G. A. Pfann

304 P. Cahuc

E. Wasmer
The Educational Attainment of Second Generation $\quad 1$ Immigrants in The Netherlands

Returns to Education and Wage Equations

5

06/01

The Wage Expectations of European College

5

06/01 Students

The Role of Social Work Norms in Job Searching

5

06/01 and Subjective Well-Being

The Role of Social Work

Economic and Social Perspectives of Immigrant Children in Germany

06/01

A Theory of Immigration Amnesties

1

06/01

Social Capital and the Uncertainty Reduction of

5

06/01 Self-Employment

Labor Market Efficiency, Wages and Employ-

2

06/01 ment when Search Frictions Interact with Intrafirm Bargaining 